\title{
Two-step process for initial capture of plasmid DNA and partial removal of RNA using aqueous two-phase systems.
}

\begin{abstract}
In this paper, a two-step process for initial capture of plasmid DNA (pDNA) and partial removal of RNA using polyethylene glycol (PEG) and di-potassium hydrogen phosphate aqueous two-phase systems (ATPS) has been investigated. A Kühni-type ATPS extraction column was prepared with $50 \mathrm{ml}(12 \%(\mathrm{w} / \mathrm{w})$ PEG 1450, 12\% (w/w) phosphate) of stationary phase and loaded with crude mobile phase $(26 \%$ (w/w) PEG $1450,4 \%(\mathrm{w} / \mathrm{w})$ phosphate and $70 \%(\mathrm{w} / \mathrm{w})$ lysate) at a flow rate of $6 \mathrm{ml} \mathrm{min}-1$ at an impeller speed of $200 \mathrm{rpm}$. The experiment was terminated after $100 \mathrm{~min}$, and after complete resettling of the phases, $45 \mathrm{ml}$ of stationary phase was harvested. During a subsequent second extraction step contained 18\% (w/w) PEG 300 and 14\% (w/w) phosphate, a proportion of RNA, which was also concentrated during the column process, was removed. It was demonstrated that the recovery of pDNA in the second bottom phase was $89.4 \%$, which was similar to the initial recovery after column extraction $(92.1 \%)$.
\end{abstract}

Keyword: Aqueous two-phase systems (ATPS); Column; Plasmid DNA (pDNA); Recovery; Two-step process. 